\title{
ENTERPRISE INNOVATION - KEY FACTOR FOR MANUFACTURING INDUSTRY 4.0
}

\author{
Catalin Gheorghe ${ }^{262}$ \\ https://doi.org/10.31410/itema.2018.709
}

\begin{abstract}
The experience of developed countries demonstrates that sustainable growth is not possible without a high degree of innovation of firms, branches and economic sectors. According to Eurostat data and the European Commission's expert reports, Romania has failed to overcome the "modest innovation" stage in the last 15 years, being included in the cluster with the lowest innovative performance, although innovation has been included as a determinant of development economic and social, in all the strategies developed in recent years, both in the EU and in Romania. Romania's innovative performance, as measured by the Synthetic Innovation Scoreboard, recorded low values compared to all member countries. Under these conditions, the transition of Romanian companies to industry 4.0 will be more difficult.

The article presents the results of a comparative study between Romania and the EU, having as central elements: types of innovation, product and process innovation, innovation activities and expenditures, organizational and marketing innovation in product and process innovation, public sector procurement and innovation, licensing, barriers to innovation and benefits due to innovation. The study also led to the identification of the main causes that led to Romania's modest position in terms of innovation. Starting from these, have been developed solutions to increase the level of innovation in Romanian enterprises.
\end{abstract}

Keywords: industry 4.0, innovation scoreboard, Romania

\section{INTRODUCTION}

I ndustry 4.0 is a significant transformation of all industrial production by unifying digital technologies and the Internet with conventional industry. In Europe, the concept was launched and supported by Germany through government programs [1]. In the US, the often-called "Smart Manufacturing", China is "Made in China 2025", and Japan "Innovation 25" [2]. States are proposing to develop an industry that launches products faster, increase flexibility and increase resource efficiency through digitization and innovation.

\section{RESEARCH ORGANIZATION}

The subject of the paper is innovation as a key element of the transition to Industry 4.0. The literature offers different models that address innovation systems with aggregated regional data Baumert (2006), Navarro (2007), Pellitero (2008), Institute for Industrial and Financial Analysis (2013), Regional Innovation Scoreboard and others [3]. Another orientation of these researches is at national level. Some studies have attempted to develop an innovative capacity indicator to the national level as: Technology Achievement Index (UNDP, 2002), Technology Index (WEF, 2003), Indicator of Technological Capabilities (Archibugi and Coco, 2004),

${ }^{262}$ Department of Engineering and Industrial Management, Transylvania University of Brasov, 29 Eroilor Street, 500036, Brasov, Romania 
MERIT Institute in Maastricht (EIS) and others [4][5].

As a benchmark for organizing research, Innovation Union Scoreboard (IUS) was chosen to help monitor the implementation of the Europe 2020 Innovation Union strategy. For this purpose the IUS provides a comparative analysis of innovation performance in EU countries, other European countries and regional neighbors. It assesses relative strengths and weaknesses of national innovation systems and helps countries identify areas they need to address [6]. The overall objective of the Scoreboard is to provide information on innovation policies at national and EU level, by tracking progress in performance of innovation within and outside the EU, as compared to other countries (Iceland, Israel, Turkey, and Ukraine).

The EU continues to improve its position relative to the United States, Japan, and Canada. However, China is catching up at three times the EU's innovation performance growth rate. Within the EU, innovation performance increased in 18 countries and decreased in 10 countries since 2010. It can be said that innovation performance has improved overall in the European Union over the last eight years. Globally, the EU continues to be less innovative than South Korea, the United States and Japan, but the performance gap has become smaller. The EU still has a considerable advance on many other countries, including China. Starting from this instrument, considered representative for European states and beyond, the study was organized as follows:

- determining Romania's position compared with all EU member states from the point of view of innovation, in the period 2010-2017;

- calculating deviations of Romania's position, in absolute and relative amounts, compared to the EU states, each year of the analysis period;

- establish causes that led to Romania's modest position during the analysis period. The study was conducted for each dimension taken into account by the indicator;

- find solutions to increase innovation in Romania for each dimension and criterion.

2.1. The general context of innovation in the $\mathbf{E} \mathbf{U}$. Based on the synthetic indicator of innovation average performance, Member States are grouped into four different performance groups:

- Sweden, Denmark, Finland, the Netherlands, United Kingdom and Luxembourg are „innovation leaders" whose innovation outcomes are well above the EU average;

- Germany, Belgium, Ireland, Austria, France and Slovenia are „strong innovators”, with innovation performances above or close to the EU average;

- Czechia, Portugal, Malta, Spain, Estonia, Cyprus, Italy, Lithuania, Hungary, Greece, Slovakia, Latvia, Poland and Croatia are below the EU average. These countries are „moderate innovators";

- Bulgaria and Romania are „modest innovators” with innovation outcomes significantly lower than the EU average (Figure 1). 
Figure 1: Innovation Union Scoreboard 2017 [7]

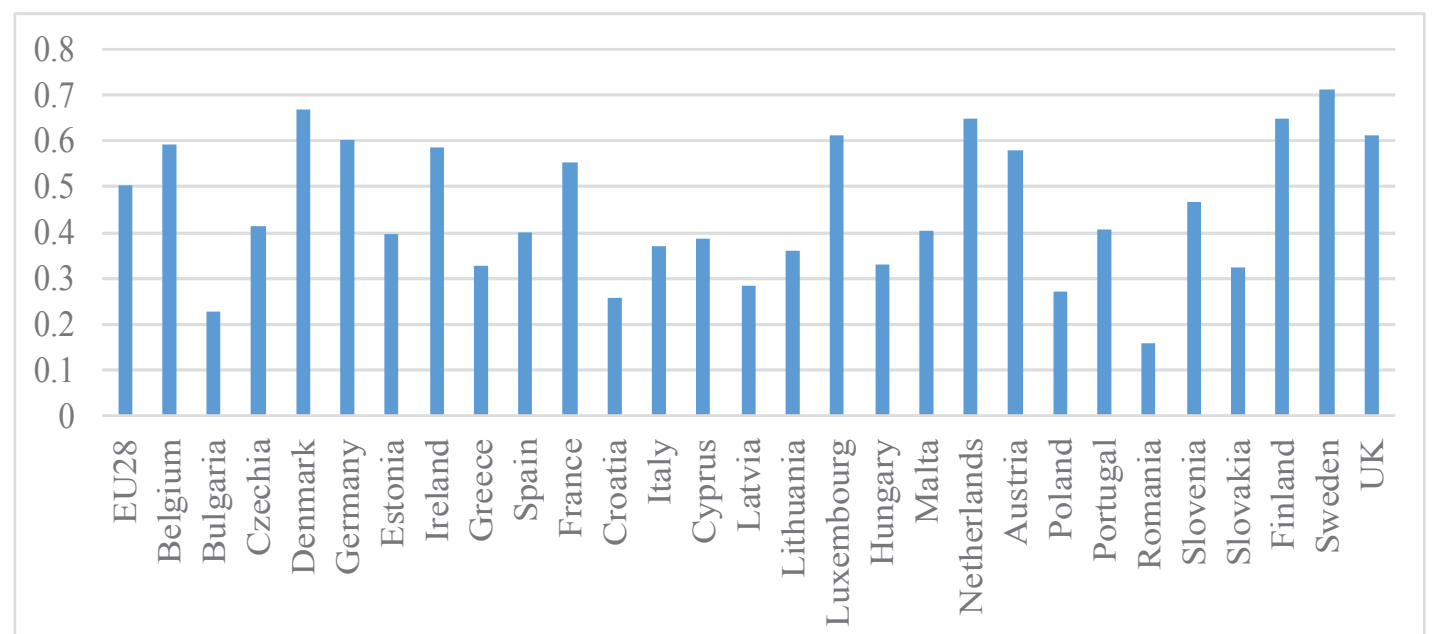

2.2 Innovation in Romania. Taking into account the 28 EU member states, Romania ranks 28 th as can be seen in Figure 1. Moreover, Romania is on a downward slope, the difference from the EU average is increasing (Figure 2). The score of Romania is 2.4 times lower than the EU average. As early as 2013, according to the European Commission, the main challenge for Romania was low competitiveness [8].

Figure 2: Innovation Scoreboard in Romania and EU [7]

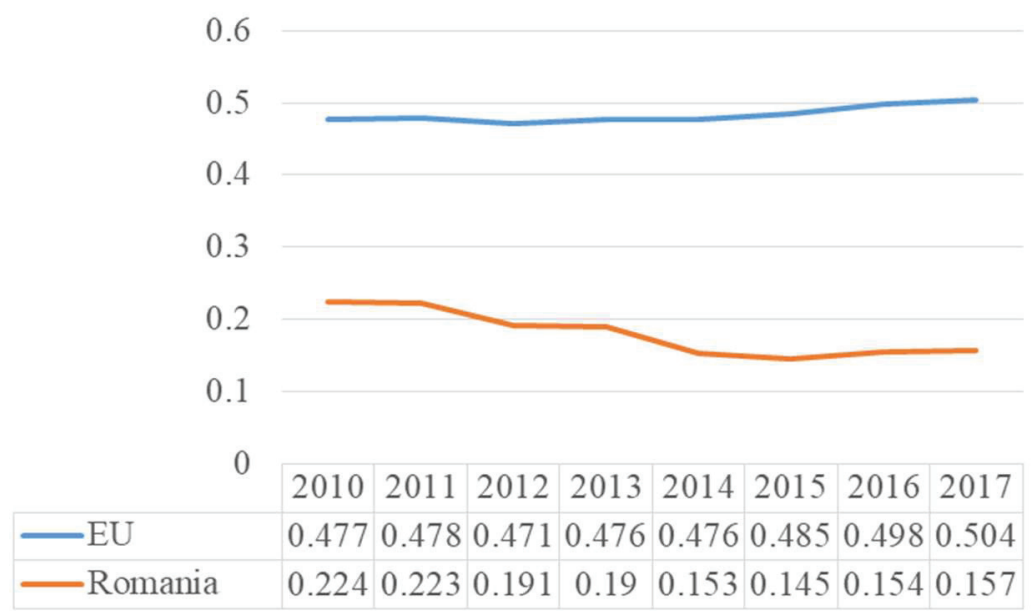

While the EU28 average annual growth of $+0.3 \%$ over the period 2010-2017, Romania has an average annual growth rate of innovation performance of $0.9 \%$. Evolution over time shows that Romania has departed from the European average, over this period, now reaching its $31,15 \%$ of the Union average value as innovation performance. Nor are prospects encouraging for Romania, even if growth is forecasted. Overall, the EU wide innovation index should grow quite strongly, with about $2.5 \%$ within two years. For Romania, an increase is estimated from 0.180 to 0.188 , below the European average [9].

The European Scoreboard quantifies three main types of indicators and ten dimensions of innovation, with a total of 28 different indicators. The organization of the research required the details of each dimension and each criterion. Statistical data was analyzed to identify the causes that led to current outcomes. Starting from these, solutions have been developed to be implemented in the economic environment, so that Romania can improve its position. Of the 28 criteria selected in the methodology for index setting are presented below the most consistent 
ones (Table 1).

Table 1: Summary innovation index for Romania [8]

\begin{tabular}{lccc}
\hline \multicolumn{1}{c}{ Dimension } & $\begin{array}{c}\text { Performance relative to } \\
\text { EU } \mathbf{2 0 1 0} \text { in }\end{array}$ & $\begin{array}{c}\text { Relative to EU } \\
\mathbf{2 0 1 7} \text { in }\end{array}$ \\
& $\mathbf{2 0 1 0}$ & $\mathbf{2 0 1 7}$ & $\mathbf{2 0 1 7}$ \\
\hline Human resources & 40.7 & 22,5 & 18,8 \\
Attractive research systems & 22,8 & 29,7 & 26,1 \\
Innovation-friendly environment & 81.1 & 96.8 & 72.3 \\
Finance and support & 48.3 & 22,4 & 20,8 \\
Firm investments & 64.9 & 13,3 & 11,9 \\
Innovators & 39,1 & 0.0 & 0.0 \\
Linkages & 53.7 & 38.1 & 37.7 \\
Intellectual assets & 8,6 & 22,5 & 22,3 \\
Employment impacts & 18,8 & 34,7 & 34,6 \\
Sales impacts & 83,4 & 66,6 & 64,0 \\
Summary innovation index & $\mathbf{4 6 . 9}$ & $\mathbf{3 2 . 9}$ & $\mathbf{3 1 . 1}$ \\
\hline
\end{tabular}

2.3 Causes of low innovation in Romania. The detailed research of each chapter of the index composition has identified the following causes:

a) The R\&D sector in the country is under-dimensioned due to low funding. In Romania, research and development per capita is spent almost 18 times less than the European average. On the other hand, demand for research and development is low, insufficient stimulus and insufficient stimulation of other economic sectors. The R\&D sector proves to be poorly connected with both the business environment and the public in general. Romania is ranked last among EU member states in terms of R\&D spending, slightly below $0.5 \%$ of GDP, well below the EU average as in Figure 3. This major strategic error is likely to compromise our chances of moving towards a production with a pronounced innovation and greater added value.

Figure 2: Gross domestic expenditure on R\&D (GERD) in Romania and EU [8]

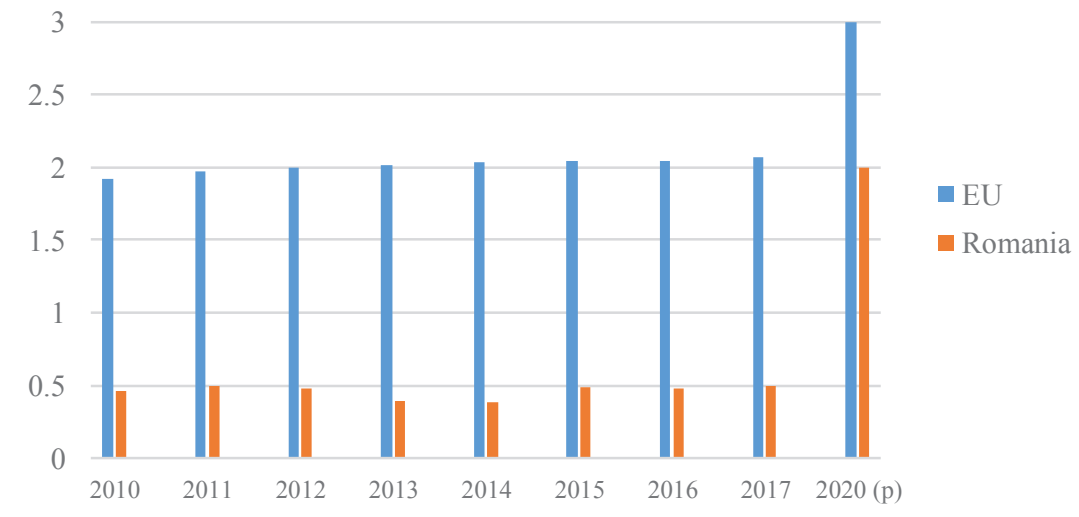

b) If international standards or domestic needs are considered, Romania does not have enough researchers. There is a lack of critical mass of human resources for the development of promising areas and, in particular, for interdisciplinary research and innovation. The number of business researchers is declining, and large companies with subsidiaries in Romania are reluctant to develop local research centers and to include 
specific activities as research and development activities (Table 2).

c) Inter-sectoral mobility is limited, having an unintended impact on the circulation of technical knowledge and innovation. Private sector access to public research infrastructures is difficult; services are limited and low use.

d) Limited marketing capacity of Romanian research and innovation results. The level of entrepreneurship, especially innovation-based is low.

e) Lack of fiscal facilities or their lack of knowledge by Romanian entrepreneurs.

f) Difficult access of SMEs to private financing sources, including private equity. The banking market does not sufficiently support entrepreneurial risk, much less on innovation. In addition, the tax environment seems unattractive for innovative startups and for investment funds that would offer support to these companies.

g) Romania continues to be below the European average in terms of intellectual property indicators. Part of this is also reflected in poor business research investment, including multinational companies.

h) The absence of an adequate number of professionals within public research organizations is a challenge in transferring technology and knowledge between public and private spaces.

Table 2: Total R\&D personnel [7]

\begin{tabular}{|l|c|c|c|c|c|c|c|c|}
\hline Year & $\mathbf{2 0 1 0}$ & $\mathbf{2 0 1 1}$ & $\mathbf{2 0 1 2}$ & $\mathbf{2 0 1 3}$ & $\mathbf{2 0 1 4}$ & $\mathbf{2 0 1 5}$ & $\mathbf{2 0 1 6}$ & $\mathbf{2 0 1 7}$ \\
\hline EU & 2541885 & 2612978 & 2670842 & 2712861 & 2778532 & 2886057 & 2961951 & 3045484 \\
\hline Romania & 26171 & 29749 & 31135 & 32507 & 31391 & 31331 & 32232 & 32586 \\
\hline
\end{tabular}

Figure 3: New doctoral graduates per thousand population aged 25-34 [7]

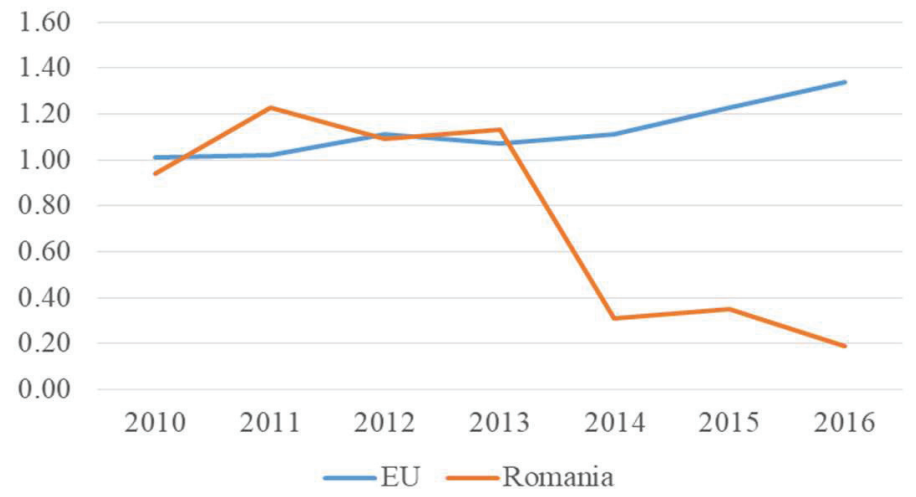

i) The access of doctoral students and recent doctors to research careers remains limited, as is the exchange of research staff between public and private organizations. Among the worrying developments is the modest presence of foreign researchers in the Romanian, along with the diminishing proportion of researchers among the employees of the private environment (Figure 3 ).

j) The presence on the international markets of the innovative products produced in the country and the global opening of the national R\&D market depends on supporting the affiliation or participation of the Romanian organizations to the regional, European or international initiatives, bodies, programs or infrastructures.

k) Under these circumstances, innovation is not a central factor in economic and social development in Romania. This is why innovation has to become one of the indispensable concerns of the scientific environment that, by leaning on it, will seek to find appropriate ways of addressing regional challenges. 
2.4 Solutions for increasing the level of innovation in Romania. After identifying the previously synthesized causes, specific solutions were generated, most important being:

a) Increasing the competitiveness of the Romanian economy through innovation. The objective is to support the performance of economic operators on global value chains. It is necessary to move from cost-based competitiveness to innovation-based competitiveness. This implies developing firms' ability to absorb state-of-the-art technology, adapt these technologies to the needs of the markets they serve, and develop technologies or services that enable them to progress on value chains.

b) Achieving by the year 2020 the critical mass of researchers needed to transform innovation into a factor of economic growth by ensuring a rapid and sustainable, numerical and qualitative development of human resources in research, development and innovation.

c) Increasing the Romanian contribution to the progress of frontier knowledge. The strategy supports the increasing international visibility of research and experimental development in Romania. The R\&D activities at the frontier of knowledge imply the formation of a critical mass of researchers in the most promising areas, maintaining the advance in niche areas, where Romanian research already has comparative advantage.

d) Create a stimulating environment for the private sector initiative through tools for entrepreneurship and the marketing of results.

e) Support smart specialization by concentrating resources in areas of research and innovation of economic relevance and potential R\&D demonstrated such as: IT security, Big Data analysis, M2M solutions and Artificial Intelligence.

f) To concentrate a significant part of innovation activities on society issues, to develop the capacity of the public R\&D sector to request and adopt research results and to address issues related to the global challenges of importance for Romania [10].

g) Developing high performing research organizations capable of becoming regional and global operators by stimulating the R\&D system defragmentation, focusing resources and prioritizing their allocation.

h) Venture capital and guarantee funds can activate the banking sector to support innovation, also leading to behavioral changes among economic operators. For this purpose, "minimis" aid schemes, seed equity capital for innovative entrepreneurs, venture capital and growth can be created "growth capital" for innovative start-ups, a credit system (microcredits, working capital loans, development investment loans) with subsidized interest for innovative SMEs.

i) The main directions of action are oriented towards the development of projects initiated by firms, competence centers, innovation infrastructure (accelerators and business incubators, technology transfer centers), doctoral programs and postdoctoral programs in priority fields, research infrastructures "roadmap", organizational performance and concentration, a strategic orientation mechanism.

\section{CONCLUSIONS}

Europe's innovation leaders have made the link between science and business and excel in the marketing of technological knowledge. The overall good performance of innovation leaders reflects a balanced national research and innovation system. Moderate and modest innovators such as Romania are characterized by unbalanced research and innovation systems. There is a political and economic consensus on the significantly positive effect of investment in innovation on productivity growth with at least the same efficiency as conventional investment. To implement the Industry 4.0 concept, companies need to plan digital transformation and increase innovation. Given the results obtained, in Romania the shift to Industry 4.0 is 
postponed, although there are significant growth opportunities.

\section{REFERENCES}

[1] Bundesministerium für Bildung und Forschung (2017) Industrie 4.0. Innovationen für die Production von Morgen available at https://www.bmbf.de, pp. 7 (in German).

[2] Thoben, K. D., Wiesner, S., Wuest, T (2017) "Industrie 4.0" and Smart Manufacturing A Review of Research Issues and Application Examples. International Journal of Automation Technology, vol.11, No. 1, pp. 5-6.

[3] Martínez Pellitero, M., Buesa M., Heijs J (2008) The IAIF Index for European Regional Innovation Systems, Instituto de Análisis Industrial y Financiero - Universidad Complutense Madrid, pp. 8-10.

[4] Desai, M., Fukuda, Parr S., Johansson C., Sagasti F. (2002) Measuring the Technology Achievement of Nations and the Capacity to Participate in the New Age. Journal of Human Development, vol. 3, No. 1, pp. 98-100.

[5] Archibugi D., Coco A., (2004) A New Indicator of Technological Capabilities for Developed and Developing Countries, CEIS Working Paper No. 44, pp. 5.

[6] European Commission (2018) European Innovation Scoreboard 2018. Methodology Report. available at https://ec.europa.eu/growth/industry/innovation/facts-figures.

[7] European Commission (2018) Eurostat available at https://ec.europa.eu/eurostat

[8] European Commission (2018) European Innovation Scoreboard 2018 available at https://ec.europa.eu/eurostat.

[9] European Commission (2013) Research and Innovation performance in EU Member States and Associated countries. Innovation Union progress at country level. Publications Office of the European Union, Luxembourg, pp. 226.

[10] Romanian Government (2014) Government Decision No. 929/2014 on the approval of the National Strategy for Research, Development and Innovation 2014 -2020. 